\title{
Depletion of endothelial progenitor cells in the peripheral blood of patients with ulcerative colitis
}

\author{
JUNYA MASUDA ${ }^{1,3}$, KEIICHI MITSUYAMA ${ }^{1,3}$, HIROSHI YAMASAKI $^{1,3}$, \\ HIROKO TAKEDATSU ${ }^{1,3}$, TAKASHI OKAMURA ${ }^{2,3}$, AKIRA ANDOH $^{4}$, \\ TOYOAKI MUROHARA ${ }^{5}$, TAKAYUKI ASAHARA ${ }^{6,7}$ and MICHIO SATA ${ }^{1}$
}

\begin{abstract}
${ }^{1}$ Division of Gastroenterology, ${ }^{2}$ Division of Hematology, Department of Medicine, Kurume University School of Medicine; ${ }^{3}$ Research Center for Innovative Cancer Therapy, Center of the 21 st Century COE Program for Medical Science, Kurume University, Asahi-machi 67, Kurume, Fukuoka 830-0011; ${ }^{4}$ Department of Internal Medicine, Shiga University of Medical Science, Seta Tukinowa, Otsu 520-2192; ${ }^{5}$ Department of Cardiology, Nagoya University Graduate School of Medicine,

65 Tsurumai-cho, Showa-ku, Nagoya 466-8550; ${ }^{6}$ Department of Regenerative Medicine, Institute of Biomedical

Research and Innovation/Stem Cell Translational Research, RIKEN Center for Developmental Biology,

2-2 Minatojima-Minamimachi, Chuo-ku, Kobe 650-0047; 7 Department of Regenerative Medicine Science,

Tokai University School of Medicine, Bohseidai, Isehara, Kanagawa 259-1193, Japan
\end{abstract}

Received September 5, 2006; Accepted October 24, 2006

\begin{abstract}
There is strong evidence to suggest that endothelial progenitor cells (EPCs) play a significant role in reendothelialization and subsequent tissue repair. This study examined the role of EPCs in inflammatory bowel disease, a disease in which impairment of mucosal healing has been implicated. Peripheral blood mononuclear cells obtained from 50 patients with ulcerative colitis (UC), 29 patients with Crohn's disease (CD), 14 patients with infectious colitis, and 35 normal control subjects were cultured in EPC medium, harvested after 7 days, and characterized by immunocytochemistry and flow cytometry. Colony assay for hematopoietic progenitor cells was also performed. Patients with active UC had a significantly decreased number of circulating EPCs as compared with healthy controls $(\mathrm{p}=0.0013)$, patients with inactive UC ( $\mathrm{p}=0.0099)$, patients with active $\mathrm{CD}(\mathrm{p}=0.0235)$ and patients with infectious colitis ( $\mathrm{p}=0.0002)$. On the other hand, patients with infectious colitis had a significantly increased number of circulating EPCs as compared with healthy controls $(\mathrm{p}=0.0406)$, patients with active $\mathrm{UC}(\mathrm{p}=0.0002)$, and patients with active $C D(p=0.0316)$. In patients with $U C$, the number of circulating EPCs was correlated with the serum hemoglobin levels $(\mathrm{r}=0.485, \mathrm{p}=0.007)$ and inversely with the platelet count
\end{abstract}

Correspondence to: Dr Keiichi Mitsuyama, Division of Gastroenterology, Department of Medicine, Kurume University School of Medicine, 67 Asahi-machi, Kurume, Fukuoka 830-0011, Japan

E-mail: ibd@med.kurume-u.ac.jp

Key words: angiogenesis, endothelial progenitor cells, hematopoietic progenitor cells, Crohn's disease, ulcerative colitis $(\mathrm{r}=-0.372, \mathrm{p}=0.0382)$. The number of hematopoietic progenitor cell colonies was comparable among patients with UC, patients with $\mathrm{CD}$, patients with infectious colitis, and healthy controls. Our observations indicate that the number of circulating EPCs in patients with UC is significantly reduced. Further studies are needed to define the mechanisms that underlie the reduction in the number of circulating EPCs and to better understand the pathophysiological consequences of this event in patients with UC.

\section{Introduction}

Ulcerative colitis (UC) and Crohn's disease (CD) are both characterized by refractory inflammatory damage in the gastrointestinal tract, dominance of the processes of injury over those of repair $(1,2)$. In general, intestinal mucosal repair consists of two major processes, epithelial regeneration and mesenchymal reconstruction. The former involves epithelial restitution, cell proliferation, maturation, and differentiation and the latter includes angiogenesis, fibrosis, and smooth muscle regeneration. Angiogenesis, a complex multistep process in the formation of new blood vessels from preexisting vessels, is central to tissue repair, as the ingrowth of newly formed vessels is necessary to ensure the supply of oxygen and nutrients to the regenerating tissue $(3,4)$. While available data to date suggest that angiogenesis and inflammation frequently occur together, evidence of the pathophysiologic relevance of angiogenesis in inflammatory bowel disease (IBD) is extremely limited (5-8).

There is now increasing evidence to suggest that neovascularization may not solely be the result of angiogenesis, but may also involve bone marrow-derived endothelial progenitor cells (EPCs). EPCs have been isolated from circulating mononuclear cells in the peripheral blood and have also been shown to be incorporated into foci of 
Table I. Clinical and laboratory characteristics in healthy control subjects, patients with infectious colitis, patients with ulcerative colitis and patients with Crohn's disease.

\begin{tabular}{|c|c|c|c|c|}
\hline & Healthy control & Infectious colitis & Ulcerative colitis & Crohn's disease \\
\hline No. of patients & 35 & 14 & 50 & 29 \\
\hline Age $(\text { years })^{\mathrm{a}}$ & $29.6 \pm 1.2$ & $29.4 \pm 3.0$ & $37.1 \pm 1.9$ & $31.3 \pm 2.5$ \\
\hline Sex (female/male) & $13 / 22$ & $6 / 8$ & $19 / 31$ & $8 / 21$ \\
\hline Disease duration (years) ${ }^{\mathrm{a}}$ & & & $7.1 \pm 1.0$ & $9.6 \pm 1.4$ \\
\hline Disease extent & & & $\begin{array}{l}\text { Entire/left-sided/rectal } \\
\quad=23 / 13 / 11\end{array}$ & $\begin{array}{l}\text { Ileal/colonic/ileocolic } \\
\qquad=3 / 2 / 24\end{array}$ \\
\hline $\begin{array}{l}\text { Treatment } \\
\text { (None/5-aminosalicylate/steroids) }\end{array}$ & & & $6 / 35 / 25$ & $3 / 22 / 10$ \\
\hline Disease activity (active/inactive) & & & $27 / 23$ & $19 / 10$ \\
\hline Leukocyte $(/ \mu 1)^{\text {a }}$ (active/inactive) & & $6679 \pm 653$ & $8206 \pm 906 / 6233 \pm 437$ & $7563 \pm 787 / 7129 \pm 320$ \\
\hline Granulocyte $(\%)^{\mathrm{a}}$ (active/inactive) & & $66.6 \pm 3.1$ & $73.4 \pm 3.2 / 61.7 \pm 2.2$ & $74.2 \pm 3.2 / 77.8 \pm 3.4$ \\
\hline Lymphocyte (\%) (active/inactive) & & $27.1 \pm 3.45$ & $21.3 \pm 3.1 / 32.6 \pm 2.0$ & $20.3 \pm 3.4 / 16.8 \pm 3.3$ \\
\hline Monocyte $(\%)^{\text {a }}$ (active/inactive) & & $5.9 \pm 0.8$ & $5.3 \pm 0.5 / 5.5 \pm 0.4$ & $5.4 \pm 0.6 / 5.4 \pm 0.7$ \\
\hline Platelet $\left(10^{4} / \mu 1\right)^{\mathrm{a}}$ (active/inactive) & & $21.9 \pm 1.9$ & $32.6 \pm 2.5 / 25.5 \pm 1.8$ & $26.2 \pm 2.6 / 22.7 \pm 0.9$ \\
\hline Erythrocyte $\left(10^{4} / \mu 1\right)^{\mathrm{a}}$ (active/inactive) & & $465 \pm 14$ & $421 \pm 16 / 484 \pm 15$ & $461 \pm 16 / 485 \pm 21$ \\
\hline CRP (mg/dl)a (active/inactive) & & $0.9 \pm 0,3$ & $1.4 \pm 0.7 / 0.1 \pm 0.0$ & $2.5 \pm 0.7 / 0.1 \pm 0.1$ \\
\hline
\end{tabular}

${ }^{\mathrm{a}}$ mean \pm SEM.

neovascularization in adults, consistent with the notion of postnatal vasculogenesis (9-13). These EPCs are mobilized endogenously in response to tissue damage (14) and/or exogenously in response to stimulation by humoral factors, such as vascular endothelial growth factor (15), granulocyte colony-stimulating factor (G-CSF) (16), erythropoietin (17), and stromal derived factor 1 (18). The involvement of EPCs in some disease conditions, including acute myocardial infarction $(19,20)$, acute lung injury $(21,22)$, chronic renal disease $(23,24)$, rheumatoid arthritis $(25,26)$, diabetes mellitus $(27,28)$ and cancers (29), is now well documented However, to date, there are no reports on the role of EPCs in patients with IBD.

On the basis of all the above observations, we hypothesized that there might be an alteration in the number of circulating number of EPCs in the peripheral blood in cases of IBD. Our results provide further insight into the pathophysiology of IBD, and also provide a useful framework of reference for developing therapeutic strategies for patients with IBD.

\section{Materials and methods}

Patients and samples. Blood samples were obtained from 50 patients with UC and 29 with CD (Table I). The diagnoses were based on characteristic clinical, endoscopic, radiological and histological features. In the UC group, clinical disease activity was analyzed according to the Lichtiger index (30). In the CD group, clinical disease activity was assessed by scoring from the International Organization for the Study of Inflammatory Bowel Disease (IOIBD) (31). Healthy, ageand sex-matched subjects served as normal controls for the assay $(n=35)$. Patients with infectious colitis served as acute inflammatory controls $(n=14)$. IBD patients were treated with 5 -aminosalicylate, steroids or both. Subjects were excluded from this study if they had diabetes mellitus, cardiovascular disease or any condition that may influence EPC kinetics (19-29). All experiments were approved by the Kurume university medical ethics committee. Informed consent was obtained from every participant.

In vitro cultures of EPCs. EPCs were cultured according to previously described techniques $(9,11)$. Briefly, peripheral blood mononuclear cells (PBMCs) were isolated by density centrifugation. After purification and three washings, $2 \times 10^{6}$ PBMCs were plated on gelatin-coated 6-well plates. Cells were cultured in Medium 199 supplemented with $20 \%$ fetal bovine serum (FBS), bovine pituitary extract to stimulate cell growth, heparin $(100 \mu \mathrm{g} / \mathrm{ml})$, and antibiotic-antimycotic (Gibco, Tulsa, OK, USA). Five microscopic fields from one well were examined for each sample on Day 7 of culture, and the number of EPCs was expressed as number of cells $/ \mathrm{mm}^{2}$. Intraassay $(n=20)$ and interassay $(n=10)$ coefficients of variation were $<5 \%$. 


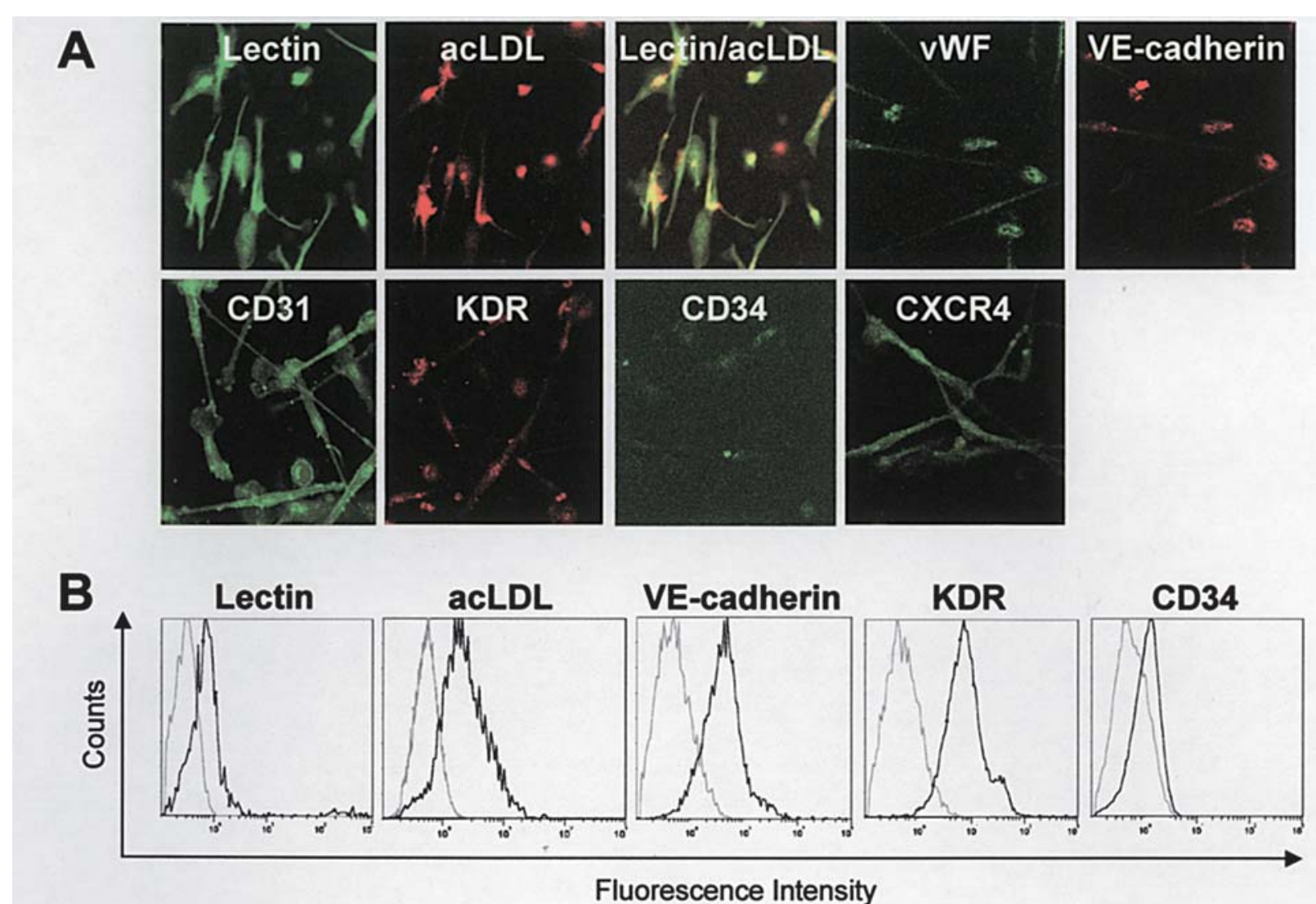

Figure 1. Characteristics of EPCs derived from peripheral mononuclear cells. (A) Immunofluorescence images of lectin (green), acetylated LDL (acLDL; red), both lectin and acLDL (yellow), von Willebrand factor (vWF; green), vascular endothelium (VE)-cadherin (red), CD31 (green), kinase domaincontaining receptor (KDR; red), CD34 (green), and CXCR4 (green) expression in EPCs. Original magnification, x200. (B) Flow cytometric analyses of lectin, acLDL, VE-cadherin, KDR and CD34 expression in EPCs. Plots show isotype controls (gray lines) vs specific antibody staining (black lines). Representative findings of healthy subjects were shown.

Fluorescence microscopy. EPCs on Day 7 of culture were fixed in equal volumes of acetone and ethanol at $-20^{\circ} \mathrm{C}$ for $10 \mathrm{~min}$. To block nonspecific binding of the primary antibodies, dishes were preincubated with Protein Block Serum-Free (Dako, Kyoto, Japan) at room temperature for $20 \mathrm{~min}$. As primary antibodies, antibodies recognizing lectin (Sigma, St. Louis, Mo, USA), acetylated LDL (acLDL; Biomedical Technologies, Stoughton, MA, USA), von Willebrand factor (vWF; Dako), vascular endothelium (VE)-cadherin (Santa Cruz Biotechnology, Santa Cruz, CA, USA), CD31 (Dako), kinase domaincontaining receptor (KDR; Santa Cruz Biotechnology), CD34 (BD, Franklin Lakes, NJ, USA) and CXCR4 (BD) were used. Dishes were incubated at room temperature for 60 min with primary antibodies in PBS and for 60 min with immunofluorescence-labeled secondary antibody. Finally, to protect fluorescence staining, the specimens were embedded in Vectorshield (Vector Laboratories, Burlingame, CA, USA).

Flow cytometric analysis. For flow cytometry, EPCs on Day 7 of culture were detached with PBS with $1 \mathrm{mM}$ ethylenediaminetetracetic acid (EDTA) followed by repeated gentle flushing through a pipette tip. The cells in suspension were labeled with immunofluorescence-tagged antibodies recognizing lectin, acLDL, VE-cadherin (Santa Cruz Biotechnology), KDR (Sigma) and CD34. Isotype-identical antibodies served as negative controls. Cells were fixed with $1 \%$ formaldehyde and analyzed by quantitative flow cytometry with the use of an EPICSR XL (Beckman Coulter, Fullerton, CA, USA).

In vitro cultures of HPCs. For analyses of hematopoietic progenitor cells (HPCs), including burst forming unit-erythroid (BFU-E); colony forming unit (CFU)-granulocyte macrophage (GM); CFU-granulocyte (G); and CFU-granulocyte, erythroid, macrophage, and megakaryocyte (GEMM), cells were suspended at a concentration of $1 \times 10^{6}$ cells $/ \mathrm{ml}$ in Iscove's modified Dulbecco's medium (IMDM) containing 2\% FBS. The cell suspensions were mixed with 10 volumes of methylcellulose-based semisolid culture medium, MethoCult ${ }^{\mathrm{TM}}$ GF H4434 (StemCell Technologies, Vancouver, Canada), containing $50 \mathrm{ng} / \mathrm{ml}$ of recombinant human stem cell factor, $10 \mathrm{ng} / \mathrm{ml}$ of granulocyte macrophage-CSF, $10 \mathrm{ng} / \mathrm{ml}$ of interleukin (IL)-3, and $3 \mathrm{U} / \mathrm{ml}$ of erythropoietin. Aliquots $(1.1 \mathrm{ml})$ were plated in duplicate in $35-\mathrm{mm}$ dishes (Falcon, Easy grip $^{\mathrm{TM}}$, Franklin lakes, NJ, USA) and incubated for 14 days in a humidified atmosphere containing $5 \% \mathrm{CO}_{2}$ at $37^{\circ} \mathrm{C}$ $(20,32)$. To quantify the mesenchymal progenitor cells in vitro, the CFU-fibroblast (F) assay (MesenCult ${ }^{\mathrm{TM}}$ basal medium for human mesenchymal stem cells, StemCell Technologies Inc.) was performed.

Statistics. Results were expressed as medians with interquartile ranges (IQRs), unless stated otherwise. Data were evaluated 


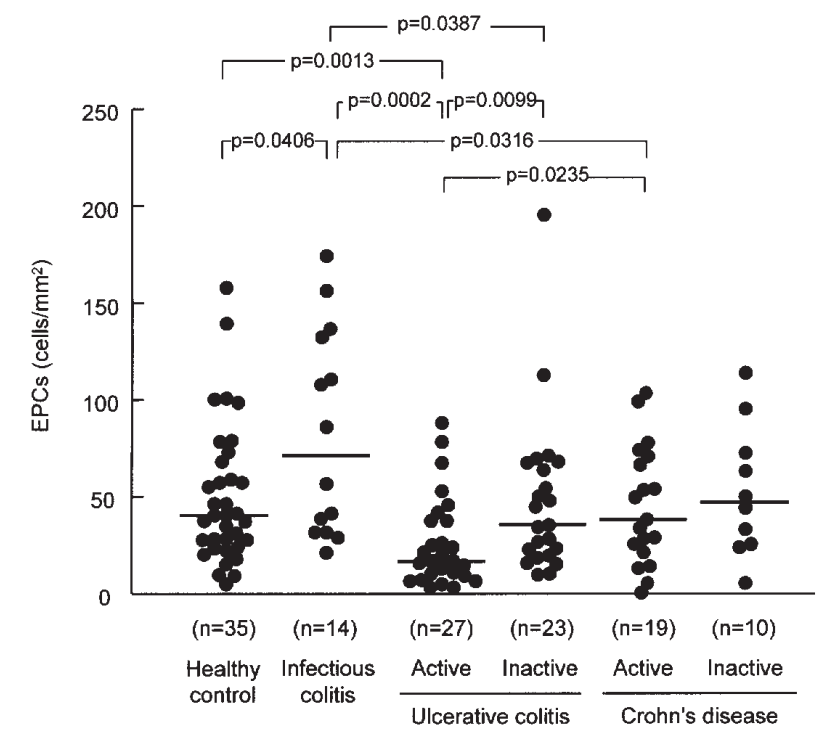

Figure 2. Quantitation of circulating EPCs in patients with ulcerative colitis, patients with Crohn's disease, patients with infectious colitis and in healthy control subjects. Solid lines represent the median values.

by Mann-Whitney's U test. Correlations were performed by determining the Spearman correlation coefficients. A p-value of $<0.05$ was considered to be significant. Statistical evaluations were performed using SPSS for Windows, version 12.0 (SPSS Inc, Chicago, IL, USA).

\section{Results}

Characterization of EPCs. As the levels of circulating EPCs in the peripheral blood are too low to be directly measured, an indirect method has been widely used to determine the number of EPCs in the peripheral blood $(9,11)$. When PBMCs were allowed to grow in culture plates coated with fibronectin, a subset of the PBMCs differentiated into EPCs and $>80 \%$ of the attached spindle-shaped cells were found to express the endothelial lineage marker. According to this established protocol, we isolated PBMCs and analyzed the number of EPCs. The EPCs were characterized as adherent cells doubly positive for lectin and acLDL, and their endothelial and hematopoietic phenotype was additionally confirmed by documenting the expression of well-established markers for EPCs, including vWF, VE-cadherin, CD31, KDR, CD34 and CXCR4 by immunostaining. Representative photomicrographs of the immunostaining are shown in Fig. 1A. Flow cytometric analysis further confirmed the endothelial and hematopoietic phenotype of the EPCs used in the present study (Fig. 1B).

Quantitation of circulating EPCs. Patients with active UC $(n=27)$ had significantly reduced numbers of circulating EPCs as compared with healthy controls $(\mathrm{n}=35, \mathrm{p}=0.0013)$, patients with inactive UC $(n=23, p=0.0099)$, patients with active $C D$ $(n=19, p=0.0235)$ and patients with infectious colitis $(n=14$, $\mathrm{p}=0.0002)$. On the other hand, patients with infectious colitis $(n=14)$ had significantly increased numbers of circulating EPCs as compared with healthy controls $(\mathrm{n}=35, \mathrm{p}=0.0406)$, patients with active UC $(\mathrm{n}=27, \mathrm{p}=0.0002)$, and patients with active $\mathrm{CD}(\mathrm{n}=19, \mathrm{p}=0.0316)$ (Fig. 2). The result was quite similar in the analysis of patients not receiving steroid treatment. The circulating number of EPCs was significantly lower in patients with active $\mathrm{UC}(\mathrm{n}=12)$ than in healthy controls $(\mathrm{n}=35, \mathrm{p}=0.0115)$, patients with inactive $\mathrm{UC}(\mathrm{n}=14, \mathrm{p}=0.1166)$, patients with active $\mathrm{CD}(\mathrm{n}=13, \mathrm{p}=0.2108)$ and patients with infectious colitis $(n=14, p=0.0014)$. The number of EPCs was significantly higher in patients with infectious colitis $(n=14)$ than in healthy controls $(\mathrm{n}=35, \mathrm{p}=0.0406)$, patients with active $\mathrm{UC}(\mathrm{n}=12, \mathrm{p}=0.0014)$, and patients with active CD $(\mathrm{n}=13$, $\mathrm{p}=0.0347$ ). Table II shows the relationship between circulating

Table II. Relationship between circulating EPCs and laboratory and clinical variables in patients with ulcerative colitis, patients with Crohn's disease and patients with infectious colitis.

\begin{tabular}{|c|c|c|c|c|c|c|}
\hline & \multicolumn{2}{|c|}{ Ulcerative colitis } & \multicolumn{2}{|c|}{ Crohn's disease } & \multicolumn{2}{|c|}{ Infectious colitis } \\
\hline & $\mathrm{r}$ & $\mathrm{n}$ & $\mathrm{r}$ & $\mathrm{n}$ & $\mathrm{r}$ & $\mathrm{n}$ \\
\hline Leukocyte & 0.177 & 32 & 0.358 & 19 & -0.125 & 14 \\
\hline Erythrocyte & 0.313 & 32 & 0.071 & 18 & 0.047 & 14 \\
\hline Hemoglobin & $0.485^{\mathrm{b}}$ & 32 & 0.015 & 18 & 0.123 & 14 \\
\hline Platelet & $-0.372^{c}$ & 32 & 0.174 & 18 & -0.310 & 14 \\
\hline CRP & -0.056 & 41 & -0.200 & 21 & -0.410 & 14 \\
\hline Clinical disease activity ${ }^{a}$ & -0.224 & 47 & -0.120 & 28 & & \\
\hline Neutrophil & 0.187 & 32 & 0.263 & 14 & -0.212 & 14 \\
\hline Eosinophil & 0.105 & 32 & -0.280 & 14 & 0.496 & 14 \\
\hline Basophil & 0.226 & 32 & 0.030 & 14 & -0.093 & 14 \\
\hline Lymphocyte & 0.128 & 32 & -0.234 & 14 & -0.096 & 14 \\
\hline Monocyte & 0.337 & 32 & 0.447 & 14 & -0.078 & 14 \\
\hline
\end{tabular}

${ }^{\mathrm{a}} \mathrm{Clinical}$ disease activity was quantified by the Lichtiger index in cases of UC and by the IOIBD score in cases of CD. ${ }^{\mathrm{b}} \mathrm{p}=0.007,{ }^{\mathrm{c}} \mathrm{p}=0.0382$. 
A. Disease duration

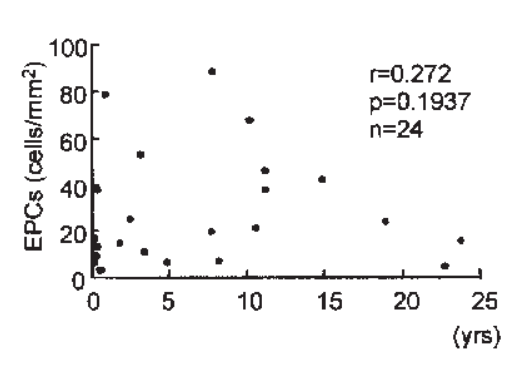

B. Disease extent

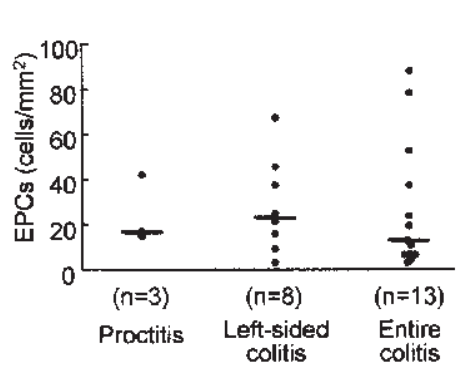

C. Medical treatment

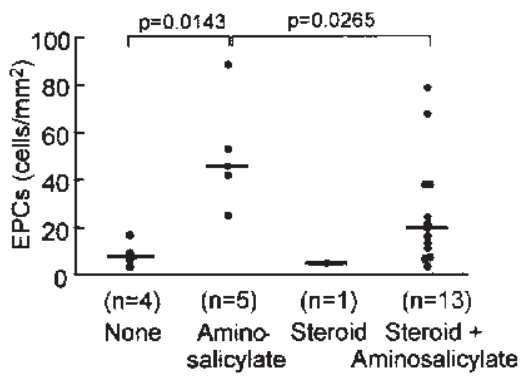

Figure 3. Number of circulating EPCs in patients with active ulcerative colitis according to the disease duration (A), the disease extent (B) and the treatment strategy employed (C). Solid lines represent the median values.

A

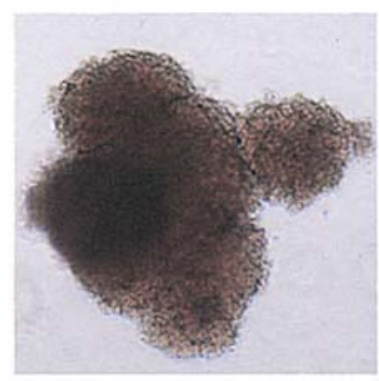

BFU-E
B

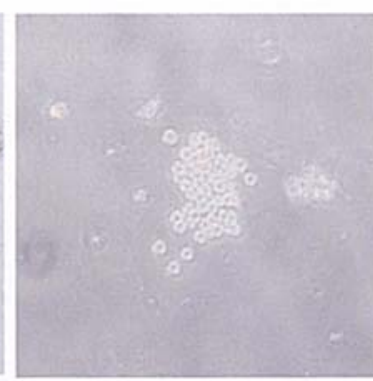

CFU-G
C

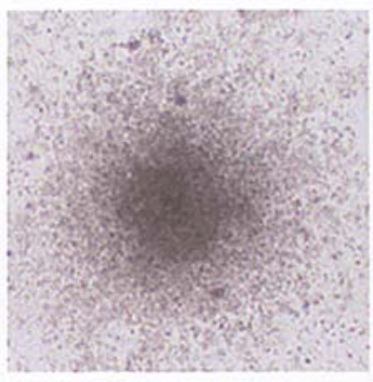

CFU-GM
D

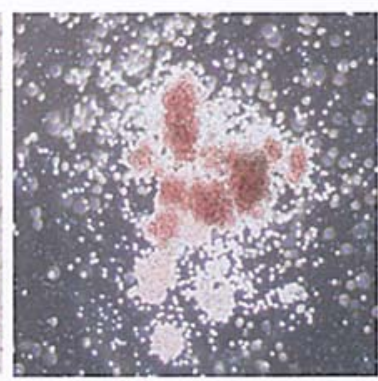

CFU-GEMM

Figure 4. Photomicrograph of a typical colony-forming units representing BFU-E (A), CFU-G (B), CFU-GM (C) and CFU-GEMM (D). Representative images from one healthy subject are shown. Original magnification, $\mathrm{x} 200$. CFU-E produces one to 2 clusters containing a total of 8-200 erythroblasts; BFU-E produces a colony containing $>200$ erythroblasts; CFU-G produces $\geq 40$ granulocytes and CFU-M produces $\geq 40$ macrophages; CFU-GM produces a colony containing $\geq 40$ granulocyte and macrophage cells; CFU-GEMM contains erythroid cells as well as $\geq 20$ granulocytes, macrophages and megakaryocytes.

EPCs and laboratory and clinical variables. In patients with $\mathrm{UC}$, the number of circulating EPCs was correlated with the serum hemoglobin level $(n=32, r=0.485, p=0.007)$ and inversely related with the platelet count $(n=32, r=-0.372$, $\mathrm{p}=0.0382$ ). No significant correlation of the circulating number of EPCs was observed with the degree of clinical disease activity $(n=47, r=-0.224, p=0.1235)$. Subanalyses performed for active UC patients (Fig. 3) showed that while the number of EPCs was decreased in cases with active disease, no correlation of the number was observed with the disease duration or disease extent. Patients treated with 5-aminosalicylate alone, but not 5-aminosalicylate plus steroids, had significantly higher number of EPCs in the peripheral blood than those not receiving medical treatment $(\mathrm{p}=0.0143)$. Also, patients treated with 5-aminosalicylate alone had higher numbers of circulating EPCs than those treated with 5-aminosalicylate plus steroids $(p=0.0265)$. However, the numbers of EPCs in all groups were too small to allow any reasonable conclusions to be drawn.

Quantitation of circulating HPCs. HPC is a putative precursor of EPCs (9-13). We assessed the overall trend in the different types of hematopoietic colonies generated from PBMCs using a CFU assay for HPCs (Fig. 4). Colony formation of HPCs was found in every subject. Nevertheless, in contrast to the results of the EPC culture assay, the colony-forming ability of each HPC, including BFU-E, CFU-G+GM and CFU-GEMM, was comparable among patients with $\mathrm{UC}$, patients with $\mathrm{CD}$, patients with infectious colitis, and healthy controls (Table III). In addition, we attempted to quantify the number of CFU-F colonies derived from the PBMCs using a CFU assay for mesenchymal cells; however, no colony formation was observed in any of the subjects with $\mathrm{UC}, \mathrm{CD}$, infectious colitis, or healthy controls.

\section{Discussion}

One theory of the pathogenesis of IBD suggests that there is a basic defect of mucosal healing in this condition, resulting in chronic intestinal inflammation $(1,2,33)$. This study examined the role of EPCs in the pathophysiology of IBD.

Our data first demonstrated a reduction in the number of circulating EPCs in patients with UC. Previous studies have reported a significant reduction in the circulating number of EPCs in other chronic diseases, such as rheumatoid arthritis (25) and diabetes mellitus $(27,28)$, as compared with the numbers in healthy individuals. Interestingly, no such reduction in the circulating number of EPCs was observed in CD, another chronic inflammatory condition. Although the precise pathogenesis of UC and CD is not fully understood, available evidence indicates that the pathogenetic mechanisms underlying the two conditions are different. Interestingly, cases with the infectious colitis, an acute inflammatory condition, were 
Table III. Evaluation of the total number of colonies derived from hematopoietic cells obtained by PBMCs cultured in vitro from healthy control subjects, patients with infectious colitis, patients with ulcerative colitis, and patients with Crohn's disease.

\begin{tabular}{|c|c|c|c|c|c|c|}
\hline & \multirow{2}{*}{$\begin{array}{l}\text { Healthy } \\
\text { control } \\
(n=45)\end{array}$} & \multirow{2}{*}{$\begin{array}{l}\text { Infectious } \\
\text { colitis } \\
(n=11)\end{array}$} & \multicolumn{2}{|c|}{ Ulcerative colitis } & \multicolumn{2}{|c|}{ Crohn's disease } \\
\hline & & & $\begin{array}{l}\text { Active } \\
(n=25)\end{array}$ & $\begin{array}{l}\text { Inactive } \\
(\mathrm{n}=16)\end{array}$ & $\begin{array}{l}\text { Active } \\
(\mathrm{n}=15)\end{array}$ & $\begin{array}{l}\text { Inactive } \\
(\mathrm{n}=11)\end{array}$ \\
\hline BFU-E & $18.0 \pm 25.3$ & $11.0 \pm 18.9$ & $9.5 \pm 15.4$ & $15.8 \pm 20.8$ & $14.5 \pm 9.3$ & $23.0 \pm 28.6$ \\
\hline CFU-G+GM & $4.0 \pm 4.6$ & $3.0 \pm 4.4$ & $2.5 \pm 5.6$ & $2.3 \pm 5.3$ & $5.0 \pm 3.4$ & $3.5 \pm 5.1$ \\
\hline CFU-GEMM & $0.0 \pm 0.5$ & $0.0 \pm 0.4$ & $0.0 \pm 0.6$ & $0.0 \pm 0.5$ & $0.0 \pm 0.5$ & $0.0 \pm 0.9$ \\
\hline Total & $24.5 \pm 32.6$ & $13.5 \pm 21.1$ & $16.5 \pm 17.9$ & $19.3 \pm 25.8$ & $22.5 \pm 18.9$ & $34.0 \pm 36.5$ \\
\hline
\end{tabular}

BFU-E, burst-forming unit-erythroid; CFU-G, colony-forming unit-granulocyte; CFU-GM, colony-forming unit-granulocyte, macrophage; CFU-GEMM, colony-forming unit-granulocyte, erythroid, macrophage, megakaryocyte. As CFU-G and CFU-GM were sometimes indistinguishable, we calculated the sum of CFU-G and CFU-GM and represented this as CFU-G+GM. The results, expressed as number of CFU-hem $/ 1 \times 10^{5}$ PBMCs, are shown as median $\pm \mathrm{IQR}$.

found to show higher numbers of circulating EPCs, suggesting that prolonged response to chronic inflammation is necessary for this pathophysiologic change. Although no direct correlation between the circulating number of EPCs and the degree of clinical disease activity has been observed in UC, it should be noted that the number of EPCs in the peripheral blood was correlated with some laboratory markers, including the serum hemoglobin level and platelet count (34).

There are several possible explanations for the reduction in the number of circulating EPCs in patients with UC. The reduction could be a byproduct of a number of mechanisms. The existence of multi-lineage- or single lineage-committed HPCs was demonstrated in the peripheral blood in the aforementioned patient groups with inflammatory conditions, with no quantitative differences in the HPC levels among the groups. Taking into consideration the contention that HPC is one putative precursor of EPCs, (9-13) the ability of HPCs to differentiate into EPCs may be impaired in patients with UC. If this were true, the factor responsible for this reduced ability of the HPCs to differentiate this event may play a crucial role in the pathophysiology of UC. Further studies are required to define the possible factors involved, such as intracellular signaling molecules, cytokines and growth factors.

An alternative explanation for the reduction in the number of EPCs in the peripheral blood might be consumption of circulating EPCs at the site of disease. It is conceivable that EPCs may be trapped in the inflamed intestinal vessels, resulting in a reduction of their numbers in the peripheral blood. In fact, this hypothesis is supported by recent observations of EPC enrichment in the inflamed rheumatoid arthritis joint (26). This hypothesis may be difficult to prove due to the lack of exclusive markers for EPCs $(12,13)$. However, it seems unlikely, at least in intestinal inflammatory conditions, since the reduction of the cell number in the peripheral blood was observed only in UC, but not in other diseases, such as $\mathrm{CD}$ or infectious colitis. Moreover, no correlation of the EPC number was observed with the UC disease extent. In addition, we must rule out the possibility of the effect of medications used in IBD patients, such as steroids or 5-aminosalicylate, on the peripheral blood count of EPCs. However, this hypothesis also seems unlikely since the reduction in the number of circulating EPCs was consistently observed in UC regardless of the steroid treatment, and the alteration of the circulating number of EPCs by the treatment with steroids and/or 5-aminosalicylate was observed in UC but not in CD (data not shown). To date, there are no reports on the effects of these drugs on hematopoiesis or EPC mobilization. Additional studies are needed to define the mechanisms that underlie the reduction in the circulating number of EPCs and to better understand the patho-physiological consequences of this event in cases of UC.

Recently, several reports have indicated bone marrow cells as a novel source of cells to regenerate the damaged intestine. Okamoto et al demonstrated that bone marrow-derived epithelial cells are distributed in the intestinal epithelial layer, particularly during epithelial regeneration after mucosal damage (35). Brittan et al, on the other hand, found that a portion of intestinal myofibroblasts, which play an important role in wound healing, are derived from the bone marrow (36). There is some circumstantial evidence to suggest that bone marrow-derived cells may be recruited into the damaged intestine, where they may repopulate and promote tissue repair. Oyama et al reported that autologous hematopoietic stem cell transplantation attenuated disease activity in patients with refractory CD (37). Dieckgraefe et al showed that the administration of GM-CSF, a potent stimulant for hematopoiesis, was effective for treating patients with active $\mathrm{CD}$ (38). These results in humans were supported by the results of animal studies demonstrating that bone marrow cells $(39,40)$ or their inducers $(41,42)$ could ameliorate experimental colitis.

The role of bone marrow-derived EPCs in the regeneration of the endothelium in mature vessels has not yet been clarified. Several experimental studies indicated a significant contribution of EPCs in reendothelialization during the recovery process from disease. A previous study showed that bone marrowderived EPCs participated in neovascularization in patients with fatal acute myocardial infarction with a history of allogenic bone marrow transplantation (43). Another report showed that EPCs were mobilized from bone marrow and accumulated within the ischemic border zone after acute myocardial infarction in animals (11). Together with these beneficial effects of EPCs, the reduction in the number of 
circulating EPCs observed in UC may cause insufficient regeneration of the endothelium, which may lead to chronicity of the disease. Defining the mechanisms that underlie EPC reduction in UC may yield important insight into the pathogenesis of the disease. Furthermore, breaking this vicious cycle with EPCs themselves or their inducers might be of benefit in the treatment of UC.

One of the limitations of the present study was the lack of exclusive markers that distinguish EPCs from native endothelial cells $(12,13)$. Indeed, mature endothelial cells may also circulate in the peripheral blood. However, the number of circulating mature endothelial cells was low, even in patients with acute myocardial infarction (10 to 100 cells $/ \mathrm{ml}$ blood) (44), whereas the circulating number of EPCs ranged from 0.3 to $1 \times 10^{4}$ cells $/ \mathrm{ml}(45,46)$. Moreover, mature endothelial cells have a low proliferative activity and do not participate in neovascularization $(43,47,48)$.

In conclusion, the results of this study indicate that the circulating number of EPCs is significantly reduced in cases of UC, and that this reduction might constitute an important pathophysiological event in cases with the disease. Further studies designed to specifically investigate the role of EPCs in the chronically inflamed bowel in cases of IBD are needed.

\section{Acknowledgements}

We thank Ms. Kazuyo Handa and Drs Atsushi Toyonaga, Osamu Tsuruta, Asuka Suzuki, Nobuo Tomiyasu, Toru Nakamura, Eitaro Taniguchi and Kazunori Harada (Division of Gastroenterology, Kurume University), Ms. Ritsuko Seki (Division of Hematology, Kurume University), Drs Yoshiaki Takeshita, Toshifumi Shimada and Yosuke Katsuda (Division of Cardiovascular Medicine, Kurume University), and Dr Haruchika Masuda (Department of Physiology, Tokai University) for their invaluable help.

\section{References}

1. MacDonald TT and Pender SL: Mechanisms of tissue injury. In: Kirsner's Inflammatory Bowel Diseases. Sartor RB and Sandborn WJ (eds). W.B. Saunders company, Philadelphia, pp163-178, 2004.

2. Bamias G, Nyce MR, De La Rue SA and Cominelli F: New concepts in the pathophysiology of inflammatory bowel disease. Ann Intern Med 143: 895-904, 2005.

3. Ferrara $\mathrm{N}$ and Kerbel RS: Angiogenesis as a therapeutic target. Nature 438: 967-974, 2005.

4. Carmeliet P: Angiogenesis in life, disease and medicine. Nature 438: 932-936, 2005.

5. Beck PL and Podolsky DK: Growth factors in inflammatory bowel disease. Inflamm Bowel Dis 5: 44-60, 1999.

6. Mori M, Stokes KY, Vowinkel T, Watanabe N, Elrod JW, Harris NR, Lefer DJ, Hibi T and Granger DN: Colonic blood flow responses in experimental colitis: time course and underlying mechanisms. Am J Physiol Gastrointest Liver Physiol 289: G1024-G1029, 2005.

7. Hatoum OA, Binion DG and Gutterman DD: Paradox of simultaneous intestinal ischaemia and hyperaemia in inflammatory bowel disease. Eur J Clin Invest 35: 599-609, 2005.

8. Hulten L, Lindhagen J, Lundgren O, Fasth S and Ahren C: Regional intestinal blood flow in ulcerative colitis and Crohn's disease. Gastroenterology 72: 388-396, 1977.

9. Asahara T, Murohara T, Sullivan A, Silver M, van der Zee R, Li T, Witzenbichler B, Schatteman G and Isner JM: Isolation of putative progenitor endothelial cells for angiogenesis. Science 275: 964-967, 1997.
10. Shi Q, Rafii S, Wu MH, Wijelath ES, Yu C, Ishida A, Fujita Y, Kothari S, Mohle R, Sauvage LR, Moore MA, Storb RF and Hammond WP: Evidence for circulating bone marrow-derived endothelial cells. Blood 92: 362-367, 1998 .

11. Asahara T, Masuda H, Takahashi T, Kalka C, Pastore C, Silver M, Kearne M, Magner M and Isner JM: Bone marrow origin of endothelial progenitor cells responsible for postnatal vasculogenesis in physiological and pathological neovascularization. Circ Res 85: 221-228, 1999.

12. Urbich C and Dimmeler S: Endothelial progenitor cells: characterization and role in vascular biology. Circ Res 95: 343-353, 2004.

13. Ingram DA, Caplice NM and Yoder MC: Unresolved questions, changing definitions, and novel paradigms for defining endothelial progenitor cells. Blood 106: 1525-1531, 2005.

14. Takahashi T, Kalka C, Masuda H, Chen D, Silver M, Kearney M, Magner M, Isner JM and Asahara T: Ischemiaand cytokine-induced mobilization of bone marrow-derived endothelial progenitor cells for neovascularization. Nat Med 5: 434-438, 1999.

15. Asahara T, Takahashi T, Masuda H, Kalka C, Chen D, Iwaguro H, Inai $\mathrm{Y}$, Silver $\mathrm{M}$ and Isner JM: VEGF contributes to postnatal neovascularization by mobilizing bone marrow-derived endothelial progenitor cells. EMBO J 18: 3964-3972, 1999.

16. Powell TM, Paul JD, Hill JM, Thompson M, Benjamin M, Rodrigo M, McCoy JP, Read EJ, Khuu HM, Leitman SF, Finkel T and Cannon RO III: Granulocyte colony-stimulating factor mobilizes functional endothelial progenitor cells in patients with coronary artery disease. Arterioscler Thromb Vasc Biol 25: 296-301, 2005.

17. Bahlmann FH, De Groot K, Spandau JM, Landry AL, Hertel B, Duckert T, Boehm SM, Menne J, Haller H and Fliser D: Erythropoietin regulates endothelial progenitor cells. Blood 103: 921-926, 2004.

18. De Falco E, Porcelli D, Torella AR, Straino S, Iachininoto MG, Orlandi A, Truffa S, Biglioli P, Napolitano M, Capogrossi MC and Pesce M: SDF-1 involvement in endothelial phenotype and ischemia-induced recruitment of bone marrow progenitor cells. Blood 104: 3472-3482, 2004.

19. Shintani S, Murohara T, Ikeda H, Ueno T, Honma T, Katoh A, Sasaki K, Shimada T, Oike Y and Imaizumi T: Mobilization of endothelial progenitor cells in patients with acute myocardial infarction. Circulation 103: 2776-2779, 2001.

20. Massa M, Rosti V, Ferrario M, Campanelli R, Ramajoli I, Rosso R, De Ferrari GM, Ferlini M, Goffredo L, Bertoletti A, Klersy C, Pecci A, Moratti R and Tavazzi L: Increased circulating hematopoietic and endothelial progenitor cells in the early phase of acute myocardial infarction. Blood 105: 199-206, 2005.

21. Burnham EL, Taylor WR, Quyyumi AA, Rojas M, Brigham KL and Moss M: Increased circulating endothelial progenitor cells are associated with survival in acute lung injury. Am J Respir Crit Care Med 172: 854-860, 2005.

22. Yamada M, Kubo H, Kobayashi S, Ishizawa K, Numasaki M, Ueda S, Suzuki T and Sasaki H: Bone marrow-derived progenitor cells are important for lung repair after lipopolysaccharideinduced lung injury. J Immunol 172: 1266-1272, 2004.

23. Choi JH, Kim KL, Huh W, Kim B, Byun J, Suh W, Sung J, Jeon ES, Oh HY and Kim DK: Decreased number and impaired angiogenic function of endothelial progenitor cells in patients with chronic renal failure. Arterioscler Thromb Vasc Biol 24: $1246-1252,2004$

24. Rodriguez-Ayala E, Yao Q, Holmen C, Lindholm B, Sumitran-Holgersson $\mathrm{S}$ and Stenvinkel P: Imbalance between detached circulating endothelial cells and endothelial progenitor cells in chronic kidney disease. Blood Purif 24: 196-202, 2006.

25. Grisar J, Aletaha D, Steiner CW, Kapral T, Steiner S, Seidinger D, Weigel G, Schwarzinger I, Wolozcszuk W, Steiner G and Smolen JS: Depletion of endothelial progenitor cells in the peripheral blood of patients with rheumatoid arthritis. Circulation 111: 204-211, 2005.

26. Ruger B, Giurea A, Wanivenhaus AH, Zehetgruber H, Hollemann D, Yanagida G, Groger M, Petzelbauer P, Smolen JS, Hoecker P and Fischer MB: Endothelial precursor cells in the synovial tissue of patients with rheumatoid arthritis and osteoarthritis. Arthritis Rheum 50: 2157-2166, 2004.

27. Tepper OM, Galiano RD, Capla JM, Kalka C, Gagne PJ, Jacobowitz GR, Levine JP and Gurtner GC: Human endothelial progenitor cells from type II diabetics exhibit impaired proliferation, adhesion, and incorporation into vascular structures. Circulation 106: 2781-2786, 2002. 
28. Vasa M, Fichtlscherer S, Aicher A, Adler K, Urbich C, Martin H, Zeiher AM and Dimmeler S: Number and migratory activity of circulating endothelial progenitor cells inversely correlate with risk factors for coronary artery disease. Circ Res 89: E1-E7, 2001.

29. Kim HK, Song KS, Kim HO, Chung JH, Lee KR, Lee YJ, Lee DH, Lee ES, Kim HK, Ryu KW and Bae JM: Circulating numbers of endothelial progenitor cells in patients with gastric and breast cancer. Cancer Lett 198: 83-88, 2003.

30. Lichtiger S, Present DH, Kornbluth A, Gelernt I, Bauer J, Galler G, Michelassi F and Hanauer S: Cyclosporine in severe ulcerative colitis refractory to steroid therapy. N Engl J Med 330: 1841-1845, 1994

31. Myren J, Bouchier IA, Watkinson G, Softley A, Clamp SE and de Dombal FT: The O.M.G.E. Multinational Inflammatory Bowel Disease Survey 1976-1982. A further report on 2,657 cases. Scand J Gastroenterol Suppl 95: 1-27, 1984.

32. Yasui K, Matsumoto K, Hirayama F, Tani Y and Nakano T: Differences between peripheral blood and cord blood in the kinetics of lineage-restricted hematopoietic cells: implications for delayed platelet recovery following cord blood transplantation. Stem Cells 21: 143-151, 2003.

33. Roediger WE: The colonic epithelium in ulcerative colitis: an energy-deficiency disease? Lancet 2: 712-715, 1980.

34. Vermeire S, Van Assche G and Rutgeerts P: Laboratory markers in IBD: useful, magic, or unnecessary toys? Gut 55: 426-431, 2006.

35. Okamoto R, Yajima T, Yamazaki M, Kanai T, Mukai M, Okamoto S, Ikeda Y, Hibi T, Inazawa J and Watanabe M: Damaged epithelia regenerated by bone marrow-derived cells in the human gastrointestinal tract. Nat Med 8: 1011-1017, 2002.

36. Brittan M, Hunt T, Jeffery R, Poulsom R, Forbes SJ, Hodivala-Dilke K, Goldman J, Alison MR and Wright NA: Bone marrow derivation of pericryptal myofibroblasts in the mouse and human small intestine and colon. Gut 50: 752-757, 2002.

37. Oyama Y, Craig RM, Traynor AE, Quigley K, Statkute L, Halverson A, Brush M, Verda L, Kowalska B, Krosnjar N, Kletzel M, Whitington PF and Burt RK: Autologous hematopoietic stem cell transplantation in patients with refractory Crohn's disease. Gastroenterology 128: 552-563, 2005.
38. Dieckgraefe BK and Korzenik JR: Treatment of active Crohn's disease with recombinant human granulocyte-macrophage colony-stimulating factor. Lancet 360: 1478-1480, 2002.

39. Brittan M, Chance V, Elia G, Poulsom R, Alison MR, MacDonald TT and Wright NA: A regenerative role for bone marrow following experimental colitis: contribution to neovasculogenesis and myofibroblasts. Gastroenterology 128: 1984-1995, 2005.

40. Komori M, Tsuji S, Tsujii M, Murata H, Iijima H, Yasumaru M, Nishida T, Irie T, Kawano S and Hori M: Involvement of bone marrow-derived cells in healing of experimental colitis in rats. Wound Repair Regen 13: 109-118, 2005.

41. Cuzzocrea S, Mazzon E, Di Paola R, Patel NS, Genovese T, Muia C, De Sarro A and Thiemermann C: Erythropoietin reduces the development of experimental inflammatory bowel disease. J Pharmacol Exp Ther 311: 1272-1280, 2004.

42. Hommes DW, Meenan J, Dijkhuizen S, Ten Kate FJ, Tytgat GN and Van Deventer SJ: Efficacy of recombinant granulocyte colony-stimulating factor (rhG-CSF) in experimental colitis. Clin Exp Immunol 106: 529-533, 1996.

43. Lin Y, Weisdorf DJ, Solovey A and Hebbel RP: Origins of circulating endothelial cells and endothelial outgrowth from blood. J Clin Invest 105: 71-77, 2000.

44. Mutin M, Canavy I, Blann A, Bory M, Sampol J and Dignat-George F: Direct evidence of endothelial injury in acute myocardial infarction and unstable angina by demonstration of circulating endothelial cells. Blood 93: 2951-2958, 1999.

45. Kalka C, Tehrani H, Laudenberg B, Vale PR, Isner JM, Asahara T and Symes JF: VEGF gene transfer mobilizes endothelial progenitor cells in patients with inoperable coronary disease. Ann Thorac Surg 70: 829-834, 2000.

46. Murohara T, Ikeda H, Duan J, Shintani S, Sasaki K, Eguchi H, Onitsuka I, Matsui K and Imaizumi T: Transplanted cord bloodderived endothelial precursor cells augment postnatal neovascularization. J Clin Invest 105: 1527-1536, 2000.

47. Isner JM and Asahara T: Angiogenesis and vasculogenesis as therapeutic strategies for postnatal neovascularization. J Clin Invest 103: 1231-1236, 1999.

48. Kalka C, Masuda H, Takahashi T, Kalka-Moll WM, Silver M, Kearney M, Li T, Isner JM and Asahara T: Transplantation of ex vivo expanded endothelial progenitor cells for therapeutic neovascularization. Proc Natl Acad Sci USA 97: 3422-3427, 2000. 